\title{
BIOPROSPECÇ̃̃O DE ISOLADOS DE Bacillus PROMOTORES DE CRESCIMENTO DE MILHO CULTIVADO EM SOLO AUTOCLAVADO E NATURAL
}

\author{
Bioprospection of Bacillus isolates promoters of corn growth in natural and sterile soil
}

\author{
Fabio Fernando de Araujo ${ }^{1}$, Renato Tadeu Guerreiro ${ }^{2}$
}

\begin{abstract}
RESUMO
Objetivou-se, neste trabalho, selecionar isolados bacterianos do gênero Bacillus em amostras de solo da região oeste paulista e avaliar o efeito de sua inoculação em milho cultivado em duas condições de solo (natural e autoclavado). Trinta e oito isolados bacterianos, caracterizados como Bacillus sp. foram avaliados previamente quanto ao antagonismo a fungos fitopatogênicos e produção de hormônio vegetal (auxinas) em laboratório. Foram selecionados 14 isolados para inoculação de milho cultivado em vasos, em casa de vegetação durante 50 dias. As avaliações efetuadas durante a condução do experimento foram: altura de plantas; número de folhas desdobradas e biomassa seca produzida aos 50 dias após a semeadura. O cultivo do milho em solo autoclavado proporcionou maior número de folhas desdobradas e produção de biomassa na planta. Os isolados bacterianos BRG-2, CAS-2, NGR-1, PNP-2, PRP-2 e TAC-2, destacaram-se como promotores de crescimento do milho, avaliado pela produção de biomassa pela planta aos 50 dias de idade. Dos oito antagonistas avaliados apenas quatro foram promotores de crescimento do milho. A maior produção de AIA não foi uma característica principal dos melhores isolados bacterianos que promoveram o crescimento do milho.
\end{abstract}

Termos para indexação: Rizobactérias, auxinas, controle biológico, Zea mays.

\begin{abstract}
The objective of this work was to select bacterial isolates of the genus Bacillus in soil samples of West of the State of São Paulo and to assess the effect of their inoculation in corn growing in two soil conditions (natural and sterilized). 38 bacterial isolates characterized as belonging to the Bacillus genus were previously evaluated regarding their antagonism to phytopathogenic fungi and their production of plant hormones (auxines) in the laboratory. The corn plants were inoculated with 14 Bacillus isolates and grown in in a greenhouse for 50 days. The evaluations made during the conduction of the trial were: plant height, number of leaves and biomass dry weight. The bacterial isolates BRG-2, CAS-2, NGR-1, PNP-2, PRP-2 and TAC-2 were able to promote maize growth. Among the best isolates four were antagonist to phytopathogenic fungi. The AIA production was not the main feature of the best bacterial isolates that promoted the growth of corn.
\end{abstract}

Index terms: Rhizobacterias, auxin, biological control, Zea mays.

(Recebido em 12 de setembro de 2008 e aprovado em 15 de setembro de 2009)

\section{INTRODUÇÃO}

A cultura do milho ocupou, em 2006, uma área em torno de 12,9 milhões de hectares no Brasil, sendo responsável por uma produção de cerca de 41,3 milhões de toneladas de grãos, apresentando um rendimento médio de $3.198 \mathrm{~kg} \mathrm{ha}^{-1}$ (Instituto Brasileiro de Geografia e Estatística-IBGE, 2008). Esse rendimento é muito inferior ao que poderia ser obtido, levando-se em consideração o potencial produtivo da cultura (Empresa Brasileira de Pesquisa Agropecuária-Embrapa, 2007). Várias causas contribuem para esse cenário, destacando-se o uso de variedades com potencial produtivo limitado, disponibilidade de água e de nutrientes no solo deficiente, utilização inadequada de época e densidade de semeadura e controle precário de insetos e plantas daninhas (Silva et al., 2003).

O efeito de rizobactérias, dentre as quais podemos destacar as do gênero Bacillus sobre o desenvolvimento de plantas são amplos, incluindo os efeitos benéficos na emergência e promoção de crescimento das plantas (Schisler, 2004), como também no antagonismo a fungos fitopatogênicos (Araújo et al., 2005). Foi observado que B. subtilis promoveu crescimento e disponibilização de nutrientes para o milho em experimento de casa de vegetação (Araújo, 2008). Araújo \& Hungria (1999) concluíram que B. subtilis (AP-3) ou seus metabólitos proporcionaram incrementos na nodulação e rendimento da soja no campo. Foi constatado também que essa mesma estirpe também produz hormonios vegetais e antibióticos

\footnotetext{
${ }^{1}$ Universidade do Oeste Paulista/UNOESTE - Faculdade de Ciências Agrárias - Rod Raposo Tavares - Km 572 - 19067-175 - Presidente Prudente, SP fabio@unoeste.br

2 Universidade do Oeste Paulista/UNOESTE - Faculdade de Ciências Agrárias - Presidente Prudente, SP
} 
(Araújo et al., 2005). Na cultura do milho, a inoculação das sementes com Azospirillum aumentou significativamente a produtividade de grãos, confirmando o efeito positivo das rizobactérias em plantas dessa espécie (Cavallet et al., 2000).

A influência das rizobactérias no crescimento das plantas são atribuída entre outros, a efeitos indiretos associados ao controle biológico de patógenos secundários (Kloepper \& Schroth, 1981). Diversos trabalhos têm destacado que esses efeitos, têm sido relacionados à produção de hormônios vegetais como: giberelinas (Holl et al., 1988); ácido indol-acético (Boronin, 1993) e ácidos láticos e succínico (Yoshikawa, 1993).

A comunidade microbiana pode variar em função da espécie vegetal e tipo do solo, pois esses influenciarão nos compostos orgânicos exsudados em quantidade e qualidade, os quais, por sua vez selecionarão ou favorecerão grupos nutricionais de organismos específicos na rizosfera (Moreira \& Siqueira, 2006). Plantas cultivadas em condições estéreis podem absorver nutrientes em menor quantidade do que na presença de microrganismos, sendo que o efeito microbiano sobre a absorção de nutrientes pode ser bastante elevado, encontrando-se aumentos de até $200 \%$ (Barber \& Martin, 1976). Esse efeito positivo ocorre devido a processos microbianos como fixação biológica de nitrogênio, micorrizas e solubilização de minerais que disponibilizam nutrientes em maior quantidade para as plantas (Moreira \& Siqueira, 2006). Objetivou-se no presente trabalho, selecionar isolados bacterianos do gênero Bacillus, em amostras de solo da região oeste paulista e avaliar sua inoculação em milho, cultivado em solo natural e autoclavado.

\section{MATERIAL E MÉTODOS}

Isolamento de bactérias do gênero Bacillus Amostras de solo (coletadas a cerca de $15 \mathrm{~cm}$ a $20 \mathrm{~cm}$ de profundidade em área agrícola de vinte municípios da região oeste paulista) foram conduzidas ao laboratório de microbiologia de solos da Faculdade de Ciências Agrárias (FCA) - UNOESTE, Presidente Prudente, SP. Após homogeneização foram retiradas alíquotas de $10 \mathrm{~g}$ de solo de cada amostra, as quais, após procedimento de diluições seriadas em água destilada estéril, foram submetidas a um choque térmico $\left(70^{\circ} \mathrm{C} 10 \mathrm{~min}^{-1}\right)$, visando selecionar os microrganismos resistentes a esse tratamento, em que se enquadram os pertencentes ao gênero Bacillus (Buchanan \& Gibbons, 1975). Posteriormente, foi efetuado o plaqueamento em meio AN (ágar nutritivo) e a incubação por 48 horas, em estufa a $28^{\circ} \mathrm{C}$. As bactérias formadoras de colônias na superfície do meio foram, então, isoladas e caracterizadas como pertencentes ao gênero Bacillus, de acordo com a metodologia descrita por Li \& Alexander (1988). Através desse procedimento foram caracterizadas 38 isolados representativos de cada localidade amostrada. Os isolados bacterianos foram então avaliados quanto ao potencial de antagonismo a fitopatógenos e produção de hormônio vegetal.

Antagonismo a fungos fitopatogênicos - Objetivouse avaliar o antagonismo foi utilizado o método de pareamento em placas de Petri contendo o meio Batata Dextrose Agar (BDA) segundo metodologia descrita por Araújo et al. (2005). Foram utilizadas as seguintes espécies de fungos fitopatogênicos: Colletotrichum truncatum $e$ Fusarium oxysporum pertencentes a coleção do laboratório de fitopatologia (Unoeste). Os fungos foram multiplicados em meio de cultura agar batata durante sete dias, após esse período, discos com diâmetro de $5 \mathrm{~mm}$ contendo o micélio do fungo foram introduzidos em quatro pontos equidistantes na superfície do meio de cultura (Agar batata), contido em placa de Petri, 24 horas antes da inoculação do isolado de Bacillus no centro da placa. As placas foram incubadas em estufa à $28^{\circ} \mathrm{C}$ por sete dias. Após esse período, foi observada a formação ou não de zona de inibição entre o isolado bacteriano e o fungo fitopatogênico.

Ensaio para avaliação de produção de AIA - As concentrações de AIA (Acido indol- acético) secretadas pelas bactérias em meio de cultura foram estimadas por método colorimétrico (Radwan et al., 2005), após o cultivo em meio líquido TSB (Trypticase Soy Agar) suplementado com $10 \mathrm{~g} \mathrm{~L}^{-1}$ de dextrose, $5 \mathrm{~g} \mathrm{~L}^{-1}$ de extrato de levedura e 5 $\mathrm{mm}$ de L-triptófano (1000 ug $\mathrm{mL}^{-1}$ ). Os isolados foram mantidos a $28^{\circ} \mathrm{C}$, no escuro sob agitação constante, durante 24 horas. Após esse período, foram centrifugados a 10000g, durante 10 minutos, para a obtenção do sobrenadante. A quantidade de AIA por ml de cultura foi estimada através da mistura de $5 \mathrm{~mL}$ de reagente de Salkowski (Ehmann, 1977) com $1 \mathrm{ml}$ do sobrenadante da cultura, seguido da leitura da absorbância em $500 \mathrm{~nm}$, após 30 minutos utilizando-se o espectrofotômetro. A concentração de AIA detectada no sobrenadante foi determinada utilizando-se curva padrão, calculada com base em doses conhecidas de AIA(Sigma).

Experimento de casa de vegetação - Com base nos ensaios anteriores 14 isolados foram selecionados, adotando-se o critério principal de antagonismo a fungos e secundário de produção de hormônios, para avaliação de crescimento do milho em casa de vegetação. $O$ experimento foi realizado em solo natural e autoclavado 
acondicionado em vasos plásticos $(5 \mathrm{~kg})$. O solo foi coletado da área experimental da Unoeste, P. Prudente, SP. Os atributos químicos do solo foram obtidos de acordo com análise química (Raij et al., 2001), com os seguintes valores: $\mathrm{pH}\left(\mathrm{CaCl}_{2} 1 \mathrm{~mol} \mathrm{~L}^{-1}\right) 6,0 ; 6 \mathrm{~g} \mathrm{dm}^{-3}$ de M.O.; $38 \mathrm{mg}$ $\mathrm{dm}^{-3} \mathrm{de} \mathrm{P}_{\text {resina }} ; 3,6 \mathrm{mmol}_{\mathrm{c}} \mathrm{dm}^{-3} \mathrm{de} \mathrm{K} ; 24 \mathrm{mmol}_{\mathrm{c}} \mathrm{dm}^{-3} \mathrm{de} \mathrm{Ca} ; 8$ mmol $\mathrm{dm}^{-3}$ de $\mathrm{Mg}$ e $51 \mathrm{mmol}_{\mathrm{c}} \mathrm{dm}^{-3}$ de CTC. Parte do solo coletado foi autoclavado $\left(127^{\mathrm{c}} \mathrm{C} 30 \mathrm{~min}^{-1}\right)$ em porções de $20 \mathrm{~kg}$ antes de ser acondicionado nos vasos plásticos. Foram semeadas três sementes de milho (Híbrido duplo RG) em cada vaso e em seguida as bactérias, previamente multiplicadas em caldo nutritivo $(3,0 \mathrm{~g}$ de extrato de levedura; 5,0g de peptona; 1,0L de agua destilada) durante cinco dias em laboratório. Foram inoculadas as sementes pela adição de $0,1 \mathrm{~mL}$ de caldo nutritivo, contendo cada isolado na concentração de $1,010^{8}$ células $\mathrm{mL}^{-1}$. Após a emergência realizou-se desbaste deixando-se uma planta por vaso $\mathrm{O}$ delineamento experimental utilizado foi um fatorial de $15 \times 2$, sendo 15 tratamentos e duas condições de solo com quatro repetições, totalizando-se 120 parcelas.

Os parâmetros avaliados durante a condução do experimento foram: altura de plantas, número de folhas de milho totalmente desdobradas e biomassa seca aos 50 dias após a semeadura. Na coleta das plantas, as raízes foram lavadas em água corrente para remoção do solo aderido e em seguida separou-se o sistema radicular da parte aérea das plantas. Após isso, o material foi colocado para secar em estufa com aeração forçada até obtenção de massa constante, sendo então pesado para obtenção da relação raiz/parte aérea e biomassa seca total. Para análise de variância utilizouse o programa estatístico SISVAR (Ferreira, 2003), utilizando-se o teste F. As médias dos tratamentos foram comparadas através do teste Scott-Knott, com 5\% de significância.

\section{RESULTADOS E DISCUSSÃO}

O desempenho dos isolados do gênero Bacillus quanto ao antagonismo a fungos e produção de hormônio (AIA) in vitro é apresentado na Tabela 1. Foi constatado que apenas $25 \%$ dos isolados apresentaram antagonismo aos fungos avaliados. Quatorze isolados foram selecionados para avaliação em experimento em casa de vegetação, por apresentarem potencial antagônico a fungos ou pela produção de AIA em maior concentração.

O efeito dos tratamentos sobre as variáveis de crescimento do milho, avaliados no experimento de casa de vegetação, bem como as interações com a condição do solo (natural e autoclavado) está apresentado no quadro resumo da análise de variância (Tabela 2). Observa-se que os isolados apresentaram efeito significativo sobre as variáveis: número de folhas desdobradas e biomassa seca total. Na avaliação da interação dos isolados com a condição do solo observouse efeito significativo nas variáveis: número de folhas e biomassa seca do milho. A condição do solo foi determinante, para efeito significativo em nível de $1 \%$ de probabilidade na maioria das variáveis avaliadas. A variável relação raiz/parte aérea não foi influenciada por nenhuma fonte de variação.

Os resultados encontrados pela inoculação das bactérias e relação com crescimento de milho estão apresentados na Tabela 3. Aos 50 dias após a semeadura, a média de altura de plantas dos tratamentos conduzidos em solo autoclavado foi superior ao solo natural. Com base nos resultados encontrados pode-se afirmar que a condição do solo alterou o crescimento do milho. O número de folhas de milho totalmente desdobradas, aos 50 dias da semeadura, revelou que o milho cultivado em solo autoclavado apresentou valor médio significativamente maior de folhas, em comparação ao milho cultivado em solo natural. Os isolados bacterianos avaliados nas plantas cultivadas na condição de solo natural não interferiram nesse parâmetro de crescimento do milho. Enquanto que os isolados CAS-2, BRG-2, NGR-1 e PNP-2 podem ter induzido as plantas de milho a formarem menor número de folhas.

$\mathrm{Na}$ avaliação de biomassa seca produzida pelo milho aos 50 dias após o plantio, observou-se que os isolados BRG-2, CAS-2, NGR-1, PNP-2, PRP-2 e TAC-2 proporcionaram incrementos no desenvolvimento do milho cultivado no solo natural (Tabela 3 ). O cultivo do milho no solo autoclavado obteve média de biomassa seca de milho superior ao cultivo no solo natural.

Observou-se que a esterilização do solo proporcionou alteração no crescimento do milho cultivado nessa condição. Isso foi confirmado pelo maior número de folhas desdobradas encontradas na avaliação efetuada aos 50 dias após o plantio. Esse aumento do número de folhas indica que essas plantas estão em estádio fenológico mais adiantado que as plantas cultivadas em solo natural (Fancelli \& Dourado Neto, 2000). A inoculação da maioria dos isolados bacterianos não influenciou significativamente o crescimento das plantas cultivadas em solo estéril. Os isolados CAS-2, BRG-2, NGR-1 e PNP-2 reduziram significativamente o número de folhas desdobradas aos 50 dias após o plantio. 
Tabela 1 - Antagonismo a fungos fitopatogênicos e produção de acido indol-acético (AIA) por isolados bacterianos de amostras de solos de municípios do oeste paulista.

\begin{tabular}{|c|c|c|c|c|}
\hline \multirow{2}{*}{$\begin{array}{l}\text { Código dos } \\
\text { Isolados }\end{array}$} & \multirow[t]{2}{*}{ Local } & \multicolumn{2}{|c|}{ Antagonismo } & \multirow{2}{*}{$\begin{array}{c}\text { AIA } \\
\left(\mu \mathrm{g} \mathrm{mL}^{-1}\right)\end{array}$} \\
\hline & & Colletotrichum truncatum & Fusarium oxysporum & \\
\hline IND-1 & Indiana & - & - & 1,51 \\
\hline IND-2 & Indiana & + & - & 5,82 \\
\hline PPT-1 & Pres. Prudente & - & - & 1,49 \\
\hline PPT-1 & Pres. Prudente & - & - & 4,75 \\
\hline CAI-1 & Caiabú & - & - & 3,34 \\
\hline CAI-2 & Caiabú & - & - & 9,27 \\
\hline RFJ-1 & Regente Feijó & + & + & 3,31 \\
\hline RFJ-2 & Regente Feijó & + & - & 7,58 \\
\hline ANH-1 & Anhumas & - & - & 0,75 \\
\hline ANH-2 & Anhumas & - & - & 4,80 \\
\hline PBN-1 & Pres. Bernardes & + & - & 1,55 \\
\hline PBN-2 & Pres. Bernardes & - & - & 8,79 \\
\hline TAC-1 & Taciba & - & + & 1,38 \\
\hline TAC-2 & Taciba & + & + & 3,28 \\
\hline MTN-1 & Martinópolis & - & - & 4,90 \\
\hline MTN-2 & Martinópolis & - & - & 7,14 \\
\hline PRP-1 & Pirapozinho & - & - & 3,90 \\
\hline PRP-2 & Pirapozinho & - & - & 10,0 \\
\hline ARA-1 & Araçatuba & - & - & 3,34 \\
\hline ARA-2 & Araçatuba & - & - & 3,65 \\
\hline PDR-1 & Pedranopólis & - & - & 4,68 \\
\hline PDR-2 & Pedranopólis & - & - & 10,1 \\
\hline RSN-1 & Rosana & - & - & 4,48 \\
\hline RSN-2 & Rosana & - & - & 9,24 \\
\hline PIA-1 & Piacatu & + & - & 2,96 \\
\hline PIA-2 & Piacatu & - & - & 4,65 \\
\hline BRG-1 & Birigui & - & - & 4,82 \\
\hline BRG-2 & Birigui & - & + & 7,28 \\
\hline ALT-1 & Alto Alegre & - & - & 7,17 \\
\hline ALT-2 & Alto Alegre & - & - & 6,51 \\
\hline PNP-1 & Penapólis & - & - & 4,58 \\
\hline PNP-2 & Penapólis & - & - & 21,3 \\
\hline CAS-1 & Castilho & - & - & 4,82 \\
\hline CAS-2 & Castilho & - & + & 7,68 \\
\hline NGR-1 & Nova Granada & - & + & 4,96 \\
\hline NGR-2 & Nova Granada & - & - & 6,68 \\
\hline RUB-1 & Rubiácea & - & - & 5,00 \\
\hline RUB-2 & Rubiácea & - & - & 15,4 \\
\hline
\end{tabular}


Tabela 2 - Análise de variância com valores do teste F para altura de plantas aos 50 dias(A50) após a semeadura, número de folhas (NDF), Biomassa seca total (BST) e relação raiz/parte aérea (R/PA) de milho, em função da inoculação de isolados bacterianos em solo natural e autoclavado.

\begin{tabular}{lcccc}
\hline Fontes de variação & A50 & NDF & BST & R/PA \\
\hline Isolados & $1,41^{\text {ns }}$ & $2,53^{* *}$ & $1,52^{*}$ & $0,92^{\text {ns }}$ \\
Solo & $9,07^{* *}$ & $280,52^{* *}$ & $16,05^{* *}$ & $1,04^{\text {ns }}$ \\
Isolados x Solo & $1,20^{\mathrm{ns}}$ & $3,90^{* *}$ & $1,98^{*}$ & $1,75^{\mathrm{ns}}$ \\
\hline C.V. $(\%)$ & 7,7 & 7,9 & 22,3 & 15,9 \\
\hline
\end{tabular}

${ }^{\mathrm{ns}}$ não significativo, *significativo a $1 \% \mathrm{e} * * 5 \%$ de probabilidade pelo teste $\mathrm{F}$.

Os isolados bacterianos avaliados neste trabalho não alteraram significativamente a relação raiz / parte aérea do milho (Tabela 2). Contudo seis isolados incrementaram a produção de biomassa das plantas, quando cultivadas em solo natural. Thakuria et al. (2004) relataram que é difícil indicar os mecanismos necessários à maior habilidade da bactéria em promover o crescimento da planta. Entretanto, sugerem que um mecanismo de promoção de crescimento pode ser aumentado, em condições de campo, na presença de comunidade microbiana complexa. É importante também enfatizar que a promoção de crescimento encontrado pela inoculação das bactérias não alterou o número de folhas desdobradas no milho, indicando que a planta estava no mesmo estádio fenológico do controle.

A maioria dos isolados que promoveram crescimento do milho não estão entre os maiores produtores de AIA em laboratório (Tabela 1). Mehnaz \& Lazarovits (2006) trabalhando com inoculação de isolados bacterianos, produtores de AIA, em milho, demonstraram que o isolado que expressou a maior produção de AIA $\left(16,8 \mu \mathrm{g} \mathrm{mL}^{-1}\right)$ não foi o que promoveu o maior crescimento das plantas, porém afirmaram que a produção de AIA foi considerada o principal mecanismo responsável pela promoção de crescimento encontrada. Patten \& Glick (1996) sugerem que a entrada adicional de AIA microbiano pode modificar a auxina endógena para nível ótimo ou acima do ótimo, resultando na indução ou inibição do crescimento da planta. A resposta da auxina depende do estágio de desenvolvimento da raiz da planta, o qual influi na composição e quantidade dos esxudatos liberados pela raiz (Pilet et al., 1979).

Os isolados bacterianos TAC-2 e NGR-1 destacaram-se como promotores de crescimento do milho apesar de não produzirem grandes quantidades de AIA em laboratório (Tabela 1). Esses isolados apresentaram-se como antagonistas de fitopatógenos e demonstram que a seleção de isolados bacterianos do solo deve ser realizada utilizando-se diferentes características intrínsecas das bactérias, com destaque ao potencial de antagonismo a fitopatógenos. A maioria dos trabalhos da literatura sobre a influência das rizobactérias promotoras do crescimento de plantas atribui esse fenômeno a um efeito indireto associado ao controle biológico de patógenos secundários (Kloepper \& Schroth, 1981).

Além dos fatores citados, o estudo da interação das rizobactérias com as plantas é relativamente recente, não se tendo ainda conhecimento detalhado desse relacionamento, ficando evidente a necessidade de outros estudos dentro desta interação visando ratificar a utilização dessas bactérias, no aumento do rendimento em culturas agrícolas. 


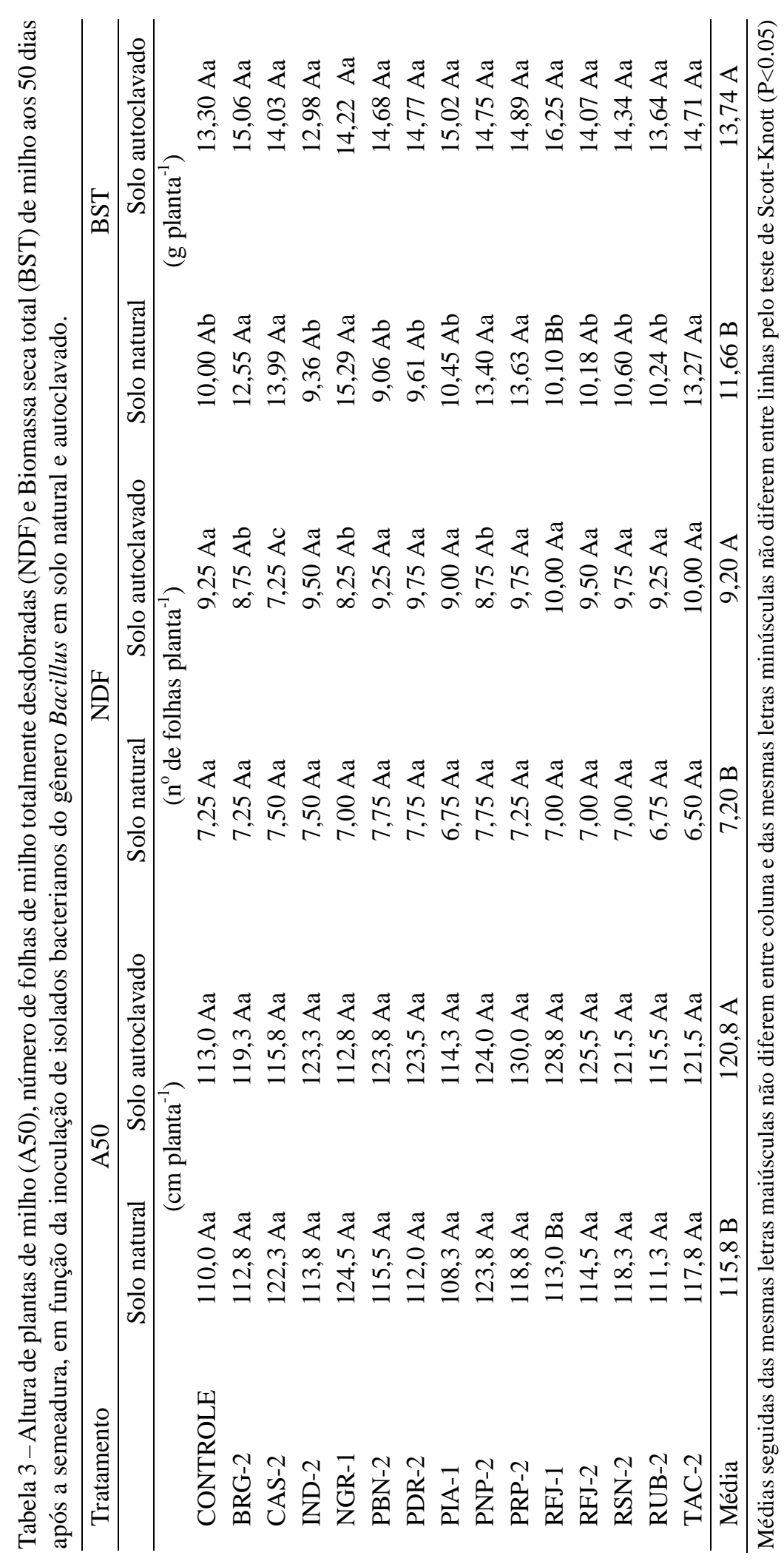

Ciênc. agrotec., Lavras, v. 34, n. 4, p. 837-844, jul./ago., 2010 


\section{CONCLUSÕES}

O cultivo do milho em solo autoclavado proporcionou maior número de folhas desdobradas e produção de biomassa na planta, aos 50 dias após a semeadura. Os isolados bacterianos BRG-2, CAS-2, NGR-1, PNP-2, PRP-2 e TAC-2, destacaram-se como promotores de crescimento do milho, avaliado pela produção de biomassa pela planta aos 50 dias de idade. Dos oito antagonistas avaliados apenas quatro foram promotores de crescimento do milho. A maior produção de AIA não foi uma característica principal dos melhores isolados bacterianos que promoveram o crescimento do milho.

\section{REFERÊNCIAS BIBLIOGRÁFICAS}

ARAÚJO, F.F. Inoculação de sementes com Bacillus subtilis, formulado com farinha de ostras e desenvolvimento de milho, soja e algodão. Ciência e Agrotecnologia, Lavras, v.32, p.456-462, 2008

\section{ARAÚJO, F.F.; HENNING, A.; HUNGRIA, M.}

Phytohormones and antibiotics produced by Bacillus subtilis and their effects on seed pathogenic fungi and on soybean root development. World Journal of Microbiology \& Biotechnology, Dordrecht, v.21, p.16391645, 2005.

ARAÚJO, F.F.; HUNGRIA, M. Nodulação e rendimento de soja co-infectada com Bacillus subtilis e Bradyrhizobium japonicum/B. elkanii. Pesquisa Agropecuária Brasileira, Brasília, v.34, p.1633-1643, 1999.

BARBER, D.A.; MARTIN, J.K. the release of organic substances by cereal roots in the soil. New Phytologist, Cambridge, v.76, p.69-80, 1976.

BORONIN, A.M. Biological control of soilborne plant pathogens by PGPR Pseudomonas isolated in Russia. In: INTERNATIONAL CONGRESS OF PLANT PATHOLOGY, 6., 1993, Montreal. Proceedings... Montreal, 1993. p.276.

BUCHANAN, R.E.; GIBBONS, N.G. Bergey's manual of determinative bacteriology. 8.ed. Baltimore: The Willians \& Wilkens, 1975. 1268p.

CAVALLET, L.E.; PESSOA, A.C.S.; HELMICH, P.R.; OST, C.F. Produtividade de milho em resposta à aplicação de nitrogênio e inoculação das sementes com Azospirillum spp. Revista Brasileira de Engenharia Agrícola e Ambiental, João Pessoa, v.4, p.129-132, 2000.

EHMANN, A. The van urk: salkowski reagent: a sensitive and specific chromogenic reagent for silica gel thin-layer chromatographic detection and identification of indole derivates. Journal of Chromatography, Armsterdan, v.132, p.267-276, 1977.

\section{EMPRESA BRASILEIRA DE PESQUISA}

AGROPECUÁRIA. Cultivo do milho. Disponível em: $\langle$ h̆ttp://www.cnpms.embrapa.br/publicacoes/milhol index.htm>. Acesso em: 20 set. 2007.

FANCELLI, A.L.; DOURADO NETO, D. Produção de milho. Guaíba: Agropecuária, 2000. 360p.

FERREIRA, D.F. SISVAR. Versão 4.3. Lavras: UFLA, 2003. 121p.

HOLL, F.B.; HOLL, F.B.; CHANWAY, C.P.; TURKINGTON, R.; RADLEY, R.A. Response of crested wheatgrass (Agropyron crystatum L.), perennial ryegrass (Lolium perenne) and white clover (Trifolium repens L.) to inoculation with Bacillus polymyxa. Soil Biology and Biochemistry, London, v.20, p.19-24, 1988.

\section{INSTITUTO BRASILEIRO DE GEOGRAFIA E} ESTATÍSTICA. Levantamento sistemático da produção agrícola. Disponível em: <www.ibge.gov.br/homet! iestatisticas/indicadores

KLOEPPER, J.W.; SCHORTH, M.N. Plant growth promoting rhizobacteria and plant growth under gnobiotic conditions. Phytopathology, Saint Paul, v.71, p.642-644, 1981.

LI, D.; ALEXANDER, M. Co-inoculation with antibioticproducing bacteria to increase colonization and nodulation by rhizobia. Plant Soil, Dordrecht, v.108, p.211-219, 1988.

MEHNAZ, S.; LAZAROVITS, G. Inoculation effects of Pseudomonas putida, Gluconacetobacter azotocaptans and Azospirillum lipoferum on corn plant growth under greenhouse conditions. Microbial Ecology, New York, v.51, p.326-335, 2006.

\section{MOREIRA, F.M.S.; SIQUEIRA, J.O. Microbiologia e bioquímica do solo. Lavras: UFLA, 2006. 729p.}


PATTEN, C.L.; GLICK, B.R. Bacterial biosynthesis of indole-3-acetic acid. Canadian Journal of Microbiology, Ottawa, v.42, p.207-230, 1996.

PILET, P.E.; ELLIOTT, M.C.; MOLONEY, M.M. Endogenous and exogenous auxin in the control of root growth. Planta, Berlin, v.146, n.4, p.405-408, 1979.

RADWAN, T.E.E.; MOHAMED, Z.K.; REIS, V.M. Aeração e adição de sais na produção de ácido indol acético por bactérias diazotróficas. Pesquisa Agropecuária Brasileira, Brasília, v.40, n.10, p.997-1004, 2005.

RAIJ, B. van; ANDRADE, J.C.; CANTARELLA, H.; QUAGGIO, J.A. Análise química para avaliação da fertilidade de solos tropicais. Campinas: IAC, 2001. $284 \mathrm{p}$.
SCHISLER, D.A. Formulation of Bacillus spp. for biological control of plant diseases. Phytopathology, Saint Paul, v.94, p.1267-1271, 2004.

SILVA, C.M.M.S.; FAY, E.F.; VIEIRA, R.F. Degradação do paclobutrazol em solos tropicais. Pesquisa

Agropecuária Brasileira, Brasília, v.38, n.10, p.12231227, 2003.

THAKURIA, D.; TALUKDAR, N.C.; GOSWAMI, C.; HAZARIKA, S.; BORO, R.C.; KHAN, M.R.

Characterization and screening of bacteria from rhizosphere of rice grown in acidic soils of Assam.

Current Science, Calcutta, v.86, p.978-985, 2004.

YOSHIKAWA, M. Succinic and latic acids as plant growth promoting compounds produced by rhizosphere Pseudomonas putida. Canadian Journal of Microbiology, Ottawa, v.39, p.1150-1154, 1993. 